\title{
RECENT DEVELOPMENTS IN THE RIGHT OF PRIVACY
}

Although invasion of the right of privacy is less frequently litigated than its closest tort companions, libel and slander, the number of cases which have recently appeared in courts of last resort indicate that the action is continuing to grow as a major remedy for tortious publications. Invasion of privacy has now been recognized in eighteen states as an independent tort action. In fifteen the resort has been made to judge-made law, ${ }^{2}$ while in three, limited statutory provisions have been enacted. ${ }^{3}$ California now appears to recognize the right independently of rights based on state constitutional provisions. ${ }^{4}$ Only two jurisdictions have flatly rejected the action,, 5 while two others have indicated a disposition to deny it. ${ }^{6}$

The action is being successfully invoked in strikingly divergent types of cases. It has been primarily used by persons seeking redress for publicity damaging to peace of mind and not deemed socially desirable. But it has also approached the action for unfair competition in its protection of the commercial use of a name, personality trait, or reputation endowed with salable good will.?

I Since I940 there have been approximately thirty cases carried to courts of last resort as compared with only ten in the prior decade. These totals do not include cases brought under the New York statute.

- Arizona, California, Florida, Georgia, Indiana, Kentucky, Louisiana, Missouri, New Jersey, North Carolina, Ohio, Oregon, Pennsylvania, and South Carolina. Illinois and Colorado have recognized the right in unreported cases. Alaska and the District of Columbia have also recognized the right. For the collected cases see I38 A.L.R. 22-Iro (I942); I68 A.L.R. 446-67 (I947); Nizer, The Right of Privacy, 39 Mich. L. Rev. 526 (194r).

${ }^{3}$ N.Y. Civil Rights Law (McKinney, rgx6) c. 6, § 50-51; Utah Rev. Stat. Ann. (I933) $\S \S$ ro3-4-7 to Io3-4-9; Va. Code Ann. (Michie, I942) $\$ 5782$. For partial text see note 57 infra. The Utah and Virginia codes are substantially similar.

4 Recovery was refused in Melvin v. Reid, II2 Cal. App. 285, 297 Pac. 9I (I93I), on the ground of invasion of privacy, but was granted on the basis of Art. I, $\S$ I of the California Constitution, which guarantees the right to pursue and obtain happiness. But in Metter v. Los Angeles Examiner, 35 Cal. App. 2d 304, 95 P. 2 d 49I (r939), and in Kerby v. Hal Roach Studios, Inc., 53 Cal. App. 2d 207, I27 P. $2 \mathrm{~d} 577$ (1942), the Reid case was treated as having adopted right of privacy, and recovery was based on this doctrine.

5 Michigan and Rhode Island. See case collections referred to in note 2 supra.

${ }^{6}$ Washington and Wisconsin. See case collections referred to in note 2 supra.

7 Application of right of privacy doctrines in the taking of fingerprints and photographs are of increasing importance, especially in the area of loyalty checks. Police officials have by now been definitely granted the right to take fingerprints and photographs of the accused before conviction. Bartletta v. McFeeley, I07 N.J. Eq. I4I, I52 Atl. I7 (I930), aff'd 109 N.J. Eq. 24x, I56 Atl. 658 (I93I), aff'd I13 N.J. Eq. 67, I66 Atl. I44 (I933); United States v. Kelly, 55 F. 2d 67 (C.C.A. 2d, I932); State ex rel. Bruns v. Clausmeier, $x 54$ Ind. 599, 57 N.E. 54I ( 1900$)$. In connection with subsequent use of these records three main rights of privacy problems have arisen: r) whether the accused may prevent distribution of the material to other police agencies; 2) whether, having been found innocent, the accused may demand the surrender or destruction of the material; and failing the second, 3) whether he may prevent the placing of his picture in a rogues' gallery.

The New Jersey court concluded in McGovern v. Van Riper, I40 N.J. Eq. 34I, 54 A. $2 \mathrm{~d} 469$ (I947), that a statute requiring the immediate forwarding of fingerprints and photographs after arrest to the state police is not unconstitutional. The first McGovern case, 137 
Recent cases in common-law jurisdictions raise critical questions as to the degree to which the plaintiff's public position and the fair comment privilege tend to narrow the scope of the privacy action. ${ }^{8}$ These cases also pose the problem of whether judicial standards of sensitivity and measurement of damages are weakening the efficacy of the action. This note deals successively with these two changing fields in the right of privacy, and a third section compares with this common-law development the exclusively statutory treatment accorded the privacy action in New York.

\section{I}

The right of privacy has been variously called the right against an invasion of personality, 9 the right to be left alone, ${ }^{x 0}$ and even the right of an individual to

N.J. Eq. 24, 43 A. 2 d 514 (1945), had prohibited a taking of the material before conviction except to identify the person as the one charged with the offense, and to facilitate recapture if the accused escaped. More important, the court had declared the statute unconstitutional so far as it allowed immediate distribution to other agencies, on the tenuous ground that the right of privacy was natural and inalienable.

In New Jersey and Indiana retention of fingerprints and photographs by the police is permissible after the accused is freed. The McGovern case rested on Fernicola v. Keenan, 136 N.J. Eq. 9, 39 A. 2d 85 (1944), where it was held that the police department should be given complete discretion. In State v. Tyndall, 66 N.E. $2 \mathrm{~d} 755$ (Ind., 1946), the same authority was relied on, but the court warned that exceptional cases might require destruction of the material.

The courts have generally enjoined the placing of photographs in a rogues' gallery. Schulman v. Whitaker, I1 7 La. 704, 42 So. 227 (1906); Itzkovich v. Whitaker, 117 La. 708, 42 So. 228 (1906); see State ex rel. Reed v. Harris, 348 Mo. 426, I53 S.W. 2d 834 (I94I), Downs v. Swann, 11 Md. 53, 73 Atl. 653 ( 1909 ). Since fingerprints are normally kept in files accessible only to experts and not to persons attempting to identify an accused, they do not raise a parallel problem. But the court in the Tyndall case recognized the real complaint to be one of publicity. Only so far as the photograph is exposed to public view with no differentiation between convicted and innocent is the right of privacy invaded. The court concluded that the violation was serious enough to justify judicial protection.

The New Jersey courts, however, as with retention of fingerprints and photographs, have held placing of the latter in a rogues' gallery to be within police discretion. Fernicola v. Keenan, ${ }_{13} 6$ N.J. Eq. 9, 39 A. 2d 851 (1944). Neither jurisdiction has adequately outlined, however, the extent to which such photographs may be the subjects of actual publicity. In view of the serious impact which publicity might have upon those in some relationship with the pictured party, and since no distinction is made as to innocence or guilt, it seems highly desirable that right of privacy should continue to be applied in these cases.

An important topic not discussed herein is recovery for invasion of privacy by radio. Will the present split of opinion in defamation as to whether radio broadcasts are more like oral or written matter carry over into the privacy field? There are dicta to the effect that oral invasion is not actionable. See Gregory v. Bryan-Hunt Co., $295 \mathrm{Ky} .345, x_{74}$ S.W. 2d 5 ro (I943), noted in 30 Corn. L.Q. 398 (1945); Brents v. Morgan, 221 Ky. 765, 299 S.W. 967 (1927). However, recovery has been allowed for invasion by radio, but without discussion of any distinctions as to oral or written matter, or of any limitations as to the number of forums where the cause of action arises and where recovery might be had. See Mau v. Rio Grande Oil, Inc., 28 F. Supp. 845 (Cal., I939); Waring v. WDAS Broadcasting Station, $327 \mathrm{~Pa}$. 433, 194 Atl. 63I (1937) (concurring opinion); The Choice of Law in Multistate Defamation and Invasion of Privacy: An Unsolved Problem, 6o Harv. L. Rev. 94I (I947).

9 Warren and Brandeis, The Right to Privacy, 4 Harv. L. Rev. 193 (1890).

ro Brents v. Morgan, 22I Ky. 765, 299 S.W. 967 (r927). 
be anti-social. ${ }^{\text {Ir }}$ The courts have consistently limited the individual's right to privacy, however, by the rule that public personages ${ }^{23}$ and people in whom the public has a legitimate interest $\mathrm{t}^{\mathrm{3}}$ may not claim protection. Stated more broadly, a person is said to lose his right to privacy to the degree to which he projects himself into public view and subjects his private life to examination by others..$^{14}$ The paradox ingrained in the action may thus be seen: The persons most likely to need the action because of the publicity surrounding them seem to be the ones who can claim no protection. Fortunately, this is not entirely true. If the invasion were invariably privileged because of public interest aroused by the publication there would be no occasion for the action. But, as in defamation, once it has been established that the publication is not privileged, the action will proceed regardless of the attendant publicity and the newsworthiness of the situation. Unlike the defamation case, however, here truth does not make all publications privileged,; ${ }^{55}$ but prior publicity may. A true statement made concerning an already well-known person may be nonactionable in defamation, and may also fail to invade privacy because of the public nature of the person's life. But if the plaintiff were not a public figure, recovery might still be had in the privacy action regardless of the truth or falsity of the statement. Questions of privilege and fair comment may be seen to play a major role in privacy cases, perhaps greater in this action than in any other.

Early cases seemed to suggest that the most important test in determining the limitations of privacy was simply whether the person had become a public figure, or whether he had been living quietly, in comparative obscurity.$^{16} \mathrm{It}$ has been suggested that the courts now recognize that "public curiosity is a mysterious thing and frequently concentrates most heavily on those least deserving of attention," ${ }^{7}$ and that the right is lost whenever public interest chances to descend upon and momentarily illuminate a particular person, entirely apart from the degree to which he is already a public figure.

What possible right of privacy then may be successfuily invoked by those persons who seek publicity and depend upon it for their success? O'Brien $v$. Pabst Sales $\mathrm{Co}^{18}$ clearly indicates that protection may be sought by this group for two dissimilar types of interest: interest in protecting feelings and sensitivi-

"Nizer, op. cit. supra note 2, at 528 .

${ }_{22}$ Martin v. F.I.Y. Theatre Co., 10 Ohio Ops. 338, 26 Ohio L. Abs. 67 (C.P., 1938); Edison v. Edison Polyform Mfg. Co., 73 N.J. Eq. 136, 67 Atl. 392 (1907); Corliss v. E. W. Walker Co., 64 Fed. 280 (C.C. Mass., 1894).

${ }^{13}$ Metter v. Los Angeles Examiner, 35 Cal. App. 2d 304, 95 P. 2d 49r (1939).

14 Warren and Brandeis, op. cit. supra note 9, at 214 .

${ }^{25}$ Mau v. Rio Grande Oil, Inc., 28 F. Supp. 845 (Cal., I939); Brents v. Morgan, 221 Ky. 765,299 S.W. 967 (1927).

${ }^{6}$ Nizer, op. cit. supra note 2 , at 540,556 .

17 Ibid., at 540 .

${ }^{18} 124$ F. $2 \mathrm{~d} 167$ (C.C.A. 5th, I94I). 
ties from adverse publicity, and interest in protection of potential earnings depending on the salable quality of a well-known name.

In the O'Brien case the plaintiff, a famous football player, was held to have lost his right of privacy with respect to his position in national sports. A brewer's use of his picture, together with pictures of the All-American football team and football schedules on a calendar advertising beer, was held privileged. The defendant had purchased the picture from the publicity department of the plaintiff's school. Because of the plaintiff's nation-wide reputation as a player, and because of his implied consent, the cause of action for invasion of privacy failed. Since the plaintiff had sought the limelight in connection with football, the decision seems sound. But it appears that the defendant still succeeded in capitalizing on the value of the plaintiff's name. It is to be noted, however, that the plaintiff made it explicit that he was not suing for the value of a possible implied indorsement; he did not desire it to be thought that he even might have indorsed the beer. The failure to state a cause of action for an implied indorsement, together with the failure to show damages from the use of the picture on the advertisement, precluded any recovery on these grounds.

If O'Brien had desired to show and could have shown the implied indorsement, there is little doubt that he could have recovered. On this theory, plaintiffs have been relatively successful in obtaining relief. The courts have allowed both damages and injunctive relief for the use without permission of a name carrying good-will and public interest. ${ }^{\mathbf{9}}$

With respect to protection against mental suffering the courts have been less clear. If O'Brien had been able to show some invasion of his personal life unconnected with that aspect of his life in which the public had a legitimate interest, he might well have recovered damages. ${ }^{20}$

The question is narrowed, for example, in the case of an actress, where publicity is vigorously sought as an aid to success. Is all publicity privileged regard-

${ }^{19}$ Eliot v. Jones, 66 N.Y. Misc. 95 , 120 N.Y. Supp. 989 (I9I0) (use of a university president's name on a cheap set of books patterned after a set edited by the plaintiff president); Foster-Milburn Co. v. Chinn, I34 Ky. 424, I 20 S.W. 364 (1909) (damages for use of a prominent citizen's indorsement of kidney pills without consent); Edison v. Edison Polyform Mfg. Co., 73 N.J. Eq. I36, 67 Atl. 392 ( $x 907)$ (injunction against unauthorized use of plaintiff's picture and indorsement on a patent medicine); Mackenzie v. Soden Mineral Springs Co., I8 N.Y. Supp. $240(\mathrm{r} 8 \mathrm{gr}$ ) (injunction against use of name and signature of a prominent physician on indorsement of medicinal preparation); cf. Uproar Co. v. National Broadcasting Co., 8 F. Supp. 358 (Mass., I934), modified by 8I F. 2d 373 (C.C.A. Ist, I936), cert. den. 298 U.S. 670 (I936) (injunction against unauthorized use of a radio announcer's name as constituting an unfair business practice); Hanna Mfg. Co. v. Hillerich \& Bradsby Co., 78 F. $2 d$ 763 (C.C.A. 5th, 1935); Derenberg, Trade-Mark Protection and Unfair Trading $\$ \$$ 150-59 (1936).

${ }^{20}$ The cases have not been directly in point. "In short, any person who engages in any pursuit or occupation or calling which calls for the approval or patronage of the public submits his private life to examination by those to whom he addresses his call, to any extent that may be necessary to determine whether it is wise and proper and expedient to accord to him the approval or patronage which he seeks." Pavesich v. New England Life Ins. Co., I 22 Ga. I9o, 200, 50 S.E. 68, 72 (Ig05); cf. Hodgeman v. Olsen, 86 Wash. 6I5, I50 Pac. II 22 (I915): Corliss v. E. W. Walker Co., 64 Fed. 280 (C.C. Mass., 1895). 
less of the person's professional standards? In a questionable lower court decision, it has been held that an unauthorized showing of an actress' picture among the burlesque advertisements in front of a theater was not actionable..$^{2 x}$ All right of privacy was held to have been lost. A more recent case, however, may give rise to another trend. In Kerby v. Bal Roach Studios ${ }^{22}$ the plaintiff, a stage actress, concert singer, and monologist of established reputation and integrity became the innocent victim of a publicity stunt ${ }^{23}$ designed to draw attention to one of the defendant's moving pictures. Here, the possibility that publication was privileged because of the plaintiff's dependence upon public esteem for her livelihood was not even discussed. Nor did the fact that the defendant did not intend to point to the plaintiff constitute a defense. This would indicate that a point may be reached beyond which it cannot be seriously contended that publicizing a publicity-seeking personage is privileged, even where done by mistake.

There is another class of persons for whom the action is perhaps more appropriately invoked. These are individuals who have become objects of public interest either unwillingly or quite by chance. With respect to them, the courts have continued to recognize a distinction between events properly and inevitably constituting public news or necessary public information and situations in which an interest has been artificially created as a spur to promote the distribu: tion of, and to call attention to, the particular publication medium.

This is not to say that the interests of society in current news need ever be jeopardized with respect to either class of plaintiffs. The courts have closely adhered to the rule that no cause of action arises where one is himself an object of

27 Martin v. F.I.Y. Theatre Co., Io Ohio Ops. 338, 26 Ohio L. Abs. 67 (C.P., I938); cf. Paramount Pictures v. Leader Press, 24 F. Supp. IoO4 (Okla., I938), rev'd on other grounds 106 F. 2 d 229 (C.C.A. roth, 1939). In Louka v. Park Entertainments, 294 Mass. 268, x N.E. 2d $4^{\mathrm{r}}$ (1936), recovery upon similar facts was allowed under Massachusetts' broad libel law. See discussion in note 48 infra.

${ }_{22} 53$ Cal. App. 2d 207, I27 P. 2d 577 (1942); cf. Marks v. Jaffa, 6 N.Y. Misc. 290, 26 N.Y• Supp. 908 (1893).

${ }^{23}$ The following letter was written in a feminine hand on pink stationery, was reproduced mechanically, and one thousand copies were sent to unknown men on a commercial mailing list. Each letter was enclosed in a pink envelope addressed in a feminine hand. It read:

"Dearest:

"Don't breathe it to a soul, but I'm back in Los Angeles and more curious than ever to see you. Remember how I cut up about a year ago? Well, I'm raring to go again, and believe me I'm in the mood for fun.

'Let's renew our acquaintanceship and I promise you an evening you won't forget. Meet me in front of Warner's Downtown Theatre at 7 th and Hill on Thursday. Just look for a girl with a gleam in her eye, and a smile on her lips and mischief on her mind!

$$
\begin{aligned}
& \text { "Fondly, } \\
& \text { "Your ectoplasmic playmate, } \\
& \text { "MaRTon KERBY." }
\end{aligned}
$$

Kerby v. Hal Roach Studios, 53 Cal. App. 2d 207, 208-9, I27 P. 2d 577, 579 (r942). The judge ably surmised the humiliating incidents that followed receipt of the letter, and the resulting chagrin of the plaintiff. 
news ${ }^{24}$ or even so closely related to someone in the news as to be inescapably included. ${ }^{25}$ In Elmhurst $v$. Shoreham Hotel ${ }^{26}$ the plaintiff was denied recovery for a radio news broadcast stating that the plaintiff, then a defendant in a widely publicized sedition trial, was in a position to overhear conversations of high officials in his employment as a waiter. The centering of interest upon him in connection with the trial had already made him a public figure, and the publication had informational value.

Other cases, however, have refused to recognize a privilege based on informational value. In Barber v. Time, Inc. ${ }^{27}$ an otherwise unknown person suffering from an unusual and embarrassing ailment recovered for publication of her picture and story in a nationally distributed news magazine. While there may clearly have been public interest, the interest would seem to follow from a story used to arouse, rather than to satisfy, curiosity. This perhaps represents a borderline case, where a slight change in facts might have led to a different result. If the disease had been a common one, there would have been little cause for humiliation and little reason for publication. Or if the same story had been published in a recognized medical journal, there would have been no recovery. ${ }^{28}$

In Sidis v. F-R Publishing $C o .{ }^{29}$ a result was reached which, if applied too broadly, might jeopardize the usefulness of the privacy notion. The court, ostensibly not limiting its decision to the New York Civil Rights Law, ${ }^{30}$ but also considering the alleged violation under the laws of California, Georgia, Kansas, Kentucky, and Missouri, ${ }^{3 x}$ concluded that the plaintiff, a former child prodigy, had failed to remove himself from the sphere of public interest although for thirty years ${ }^{32}$ he had sought oblivion. The court conceded that under the War-

${ }^{4}$ Metter v. Los Angeles Examiner, 35 Cal. App. 2d 304, 95 P. 2d 49r (r939); Sweenek v. Pathé News Syndicate Co., I6 F. Supp. 746 (N.Y., I936); cf. Middleton v. News Syndicate Co., I62 N.Y. Misc. 5I6, 295 N.Y. Supp. 120 (1937).

${ }_{25}$ Martin v. New Metropolitan Fiction, I39 N.Y. Misc. 290, 248 N.Y. Supp. 359 (193I), rev'd without opinion 237 App. Div. 863, 260 N.Y. Supp. 972 (r932); Jones v. Herald Post Co., 230 Ky. 227, I8 S.W. 2d 972 (I929); Hillman v. Star Pub. Co., 64 Wash. 69I, I 7 Pac. 594 (I9II).

${ }^{26} 58$ F. Supp. 484 (D.C. I945), aff'd 153 F. $2 d 467$ (App. D.C., I946).

${ }^{27} 348$ Mo. II 99 , I 59 S.W. 2d $29 \mathrm{I}$ (I942).

${ }^{28}$ Compare Feeney v. Young, I9r App. Div. 5or, I8I N.Y. Supp. 48I (r920) (public showing of movie taken of caesarian section where consent was given only for showing before medical societies held actionable); Ops. N.Y. Att'y. Gen. 374 (r934) (attorney general held that cancer photographs might not be exhibited at a state fair without consent).

${ }^{29}$ II $3_{3}$ F. 2d 806 (C.C.A. 2d, 1940).

${ }^{30}$ For partial text see note 57 infra.

${ }^{3 x}$ The plaintiff's first cause of action alleged violation of right of privacy under the law of these five jurisdictions. The court said, "Under the mandate of Erie R. Co.v. Tompkins ... we face the unenviable duty of determining the law of five states on a broad and vital public issue which the courts of those states have not even discussed." Ir3 F. 2d 806, 808 (C.C.A. 2d, I940).

${ }^{32} \mathrm{Ibid}$., at 809 ; cf. Mau v. Rio Grande Oil, Inc., 28 F. Supp. 845 (Cal., I939) (one year elapsed between the time plaintiff was in the news and the time the incident was revived by broadcasting); Melvin v. Reid, xx 2 Cal. App. 285, 297 Pac. 9I (I93I) (seven years elapsed between the time of former publicity and the time the incident was revived by a moving picture). 
ren-Brandeis view, ${ }^{33}$ the plaintiff's right of privacy would have been invaded. But its argument was that "everyone will agree that at some point the public interest in obtaining information becomes dominant over the individual's desire for privacy," 34 and apparently concluded that old news is always legitimate news. Under the then existing law of privacy in the above-named jurisdictions, which the court purported to follow, it is questionable whether this decision should have been reached. ${ }^{35}$ The result emphasizes clearly the danger of allowing an artificial stimulation of interest in a person otherwise undesirous of the public light to pass as legitimate news or information.

Courts in privacy actions need not and should not rely simply upon whether the plaintiff is or has been a public figure, or has never been heard of before. The analysis should lie, rather, along the lines suggested by the discussion of the cases above: The source and the reason for the publicity should be examined, with a distinction drawn between items of such vital newsworthiness that the public is entitled to learn of them, and publications of such transient interest that the value in education or information is outweighed by the humiliation and unhappiness caused to the person who is the subject of the publicity. Public curiosity is not so great a mystery as to reveal no causal basis. Examination of that basis should aid in separating those who have and have not lost their right to privacy.

\section{II}

Of striking importance in the privacy action are the problems arising in connection with the determination of proper remedies. While properly classified as questions of procedure, their determination may as effectively bar a plaintiff from the relief sought as a failure substantively to state a good cause of action.

Fortunately, the privacy action has remained free from some of the classic difficulties which have characterized the law of defamation. Injunctive relief, for example, conspicuous in its absence from the defamation field, ${ }^{36}$ is now and has

${ }_{33}$ Warren and Brandeis, op. cit. supra note 9.

${ }^{34}$ Sidis v. F-R Publishing Co., Ix3 F. 2d 806, 809 (C.C.A. 2d, I940).

35 The District Court briefed the leading cases of the named jurisdictions and added: "Although the right of privacy has been recognized and protected in these states where exceptional circumstances have existed and this right had been unfairly imposed upon, or when an unauthorized use has been made of one's name or picture for commercial purposes or adcertising, no decision of the courts in these states has been cited by counsel, nor have I found any which held the 'right of privacy' to be violated by a newspaper or magazine publishing a vorrect account of one's life or doings, or a picture, except under abnormal circumstances which do not exist in the case at bar." 34 F. Supp. I9, 20-2I (N.Y., I938). The Circuit Court of Appeals repeated this language. The courts seem to indicate that they must have a precedent with the facts identical to those in the Sidis case before they would allow recovery. Neither the fact situation differences as to the type of publication medium nor the so-called absence of "exceptional" or "abnormal" circumstances stand up very well upon a close comparison of the cases. Many cited by the court contain far more common situations, such as wrongful use for advertisement of photographs; in many, far less humiliation and anguish must have been felt by the plaintiffs.

${ }^{36}$ Koussevitzky v. Allen, Towne \& Heath, I88 N.Y. Misc. 479, 68 N.Y.S. $2 d 779$ (I947), aff'd 272 App. Div. 759, 69 N.Y.S. 2d 432 (1947). 
for many years been granted in the privacy action. The courts, at first straining to find a property interest, ${ }^{37}$ today allow plaintiffs the opportunity to prevent or terminate the publication of photographs,,$^{38}$ endorsements, ${ }^{39}$ and fingerprints..$^{\circ}$

More troublesome problems, however, arise in connection with the ascertainment of damages. Their measurement in the good will cases presents an orthodox problem. But most cases involve protection against or a remedy for the humiliation and mental anguish that accompany the dissemination of facts which the person would rather have left unpublished. It is the recovery for primarily this type of injury that distinguishes right of privacy from the remedy for injury to character and reputation afforded by the law of defamation, and from the remedy for physical injury resulting from injurious language, typified in Wilkinson v. Downton. ${ }^{4 \mathrm{I}}$

The language of the Florida Supreme Court in Cason v. Baskin ${ }^{2}$ illustrates the difficulties that arise. In this case, the first to establish the right of privacy in that state, the court found a violation of the right of privacy in the use of the plaintiff's personality and first name for a main character in a novel, although the portrayal was of a "fine and attractive personality." But the court allowed only nominal damages. It is to be noted that substantial damages were denied because "no mental anguish-no loss of friends or respect in the communityno injury to character or reputation ..." 43 were shown.

This suggests that courts must form some standard by which the sensitivity of a plaintiff may be measured. It is said that substantial damages are recoverable although only mental anguish is suffered.44 But how are the courts to deal with differences between individuals, especially with respect to sensitivity?45

It has been said that the right of privacy is not designed for the overly sensitive, ${ }^{46}$ and that there is an invasion only when the actions complained of would

${ }^{37}$ Chappell v. Stewart, 82 Md. 323, 33 Atl. 542 (I896). But see Munden v. Harris, I53 Mo. App. 652, I34 S.W. 1076 (r9I1).

${ }^{38}$ Bazemore v. Savannah Hospital, I7I Ga. 257, I55 S.E. 194 (r930).

39 See note 19 supra.

${ }^{10}$ See discussion in note 7 supra.

4 [r897] 2 Q.B. 57. Recovery for "mental anguish" from the invasion of privacy must exclude the type of mental suffering resulting from physical pain, or from the scorn of others. The term is difficult to define, and is necessarily poor, but the gist of its meaning is understandable from a survey of the fact situations found in the cases.

${ }^{43}$ I55 Fla. 198, 20 So. $2 \mathrm{~d} 243$ (1944), rev'd as to damages 30 So. $2 \mathrm{~d} 635$ (I947).

${ }^{43} 30$ So. $2 \mathrm{~d} 635,640$ (Fla., x 947 ).

44 Rhodes v. Graham, 238 Ky. 225, 37 S.W. 2d 46 (I93I); Brents v. Morgan, 22r Ky. 765, 299 S.W. 967 (I927); Munden v. Harris, I53 Mo. App. 652, I34 S.W. I076 (I9II).

45 "Since, then, the propriety of publishing the very same facts may depend wholly upon the person concerning whom they were published, no fixed formula can be used to prohibit obnoxious publications." Warren and Brandeis, op. cit. supra note 9, at 215.

${ }^{6}$ Pound, Interests of Personality, 28 Harv. L. Rev. 343, 362-63 (I9I5); 4 Rest., Torts $\S 867$ (d) (I939). 
shock a man of ordinary sensibilities. ${ }^{47}$ But if the notion of protecting only those of ordinary sensibilities is overemphasized, there is danger that the privacy action as it has now developed in preventing and relieving otherwise remediless injuries to the personality may be weakened. The language in the Cason case illustrates a tendency in this direction. Right of privacy, in a very real sense, begins where the law of defamation ends. The standard applied in defamation cases is a community standard, concerned with what the community thinks of the plaintiff, irrespective of his personal feelings. In the Cason case, however, since the court did find an invasion of privacy, it could also plausibly have found that the plaintiff had been subjected to unwarranted publicity. Discomfort might well have followed even though the publication may have been favorable to the plaintiff. Instead, the court seems to have substituted a standard of character and reputation for a standard of ordinary sensibilities. Thus in every case where the plaintiff's reputation has not suffered the conclusion apparently would be that he is, in effect, over-sensitive and should not recover. This approach tends only to confuse the distinction between right of privacy and defamation and to deny the protection to be afforded against mental suffering. $4^{8}$

Cason v. Baskin points up further obstacles to the recovery of damages. Granted that a plaintiff has a cause of action, how may he prove mental anguish, and what instructions must be given the jury? In Brents v. Morgan ${ }^{49}$ the court directed that the following instructions be given on retrial: "You will find for the plaintiff such sum in damages, if any, as will reasonably compensate him for any mental pain, humiliation, or mortification caused to him resulting directly from the posting of the notice, not to exceed, however, the sum of $\$ 6,500 .{ }^{\prime}{ }^{\circ}$ Usually the appellate courts indicate that ascertainment of damages is to follow the same lines as in a suit for breach of promise or alienation of affections. The obvious difficulty is that in those actions, damages for mental suffering are parasitic, and not the paramount source of recovery. In Cason v. Baskin more than nominal damages were refused because the plaintiff failed to prove mental anguish. ${ }^{\mathrm{s}} \mathrm{It}$ is submitted, however, that a different result should obtain. The ra-

47 Schuyler v. Curtis, 147 N.Y. 434,42 N.E. 22 (1895).

${ }_{48}$ Massachusetts has adopted a doctrine allowing a broad recovery under libel, which takes into consideration mental suffering. "Modern cases have made it possible to reach certain indecent violations of privacy by means of the law of libel, on the theory that any writing is a libel that discredits the plaintiff in the minds of any considerable and respectable class in the community though no wrongdoing or bad character is imputed to him." Themo v. New England Newspaper Pub. Co., 306 Mass. 54, 56, 27 N.E. 2d 753, 754 (r94o). This doctrine has been liberally applied. See cases collected in the Themo case, ibid. See also Youssoupoff $v$. M-G-M Pictures, 50 T.L.R. 58I (1934), noted in 5I L. Q. Rev. 28x (1935). Here, recovery for libel was allowed the plaintiff for her portrayal in a motion picture as being ravished by Rasputin. The court deemed this libel despite doubts as to any injury to character and reputation, reasoning that if the picture caused people to shun the plaintiff, it was libelous. Right of privacy might easily cover this type of case.

1922 Ky. 765 , 299 S.W. 967 (1927).

so Ibid., at 774-75, 97 I.

${ }^{5 x}$ I55 Fla. 198,20 So. $2 d$ d 243 (r944), rev'd as to damages 30 So. $2 d 635$ (r947). See note 43 supra and accompanying text. 
tionale behind the privacy action is, in the greater number of cases, the allowance of pecuniary compensation for mental suffering. Proof of such suffering is difficult, and may hinge only upon the skill and ingenuity of the trial lawyer. In general, it has been left to the jury to decide to what extent this proof has been successful.

The uncertainties of such a system of damages might warrant the adoption of a technique somewhat different from that ordinarily used. Because of the obvious difficulties attached to the measurement of mental suffering, it seems reasonable to conclude, keeping in mind the rationale of the privacy action, that once a court has found that there has been a legal invasion of privacy it should also find that the plaintiff has suffered a substantial amount of mental anguish. Mental suffering should be assumed to coincide with a judicially determined invasion of privacy.

The finding of nominal damages in the Cason case in effect denies the invasion altogether. ${ }^{52}$ Furthermore, the award of nominal damages gives the plaintiff no advantage that he would not have if the verdict were for the defendant..53 So, rather than find an invasion of privacy and award only a pittance, the courts should more logically do one of two things-either find no invasion at all or grant substantial damages upon the proof of a good cause of action. The actual amount of damages would be left for the decision of the trier of facts, as is customary.

Thus, the court might instruct the jury that a good cause of action carries with it the unqualified right to substantial damages, emphasizing that failure to show or mere difficulty in showing actual damages, physical harm, or loss of respect or social standing did not prejudice this right. ${ }^{54}$ Furthermore, the court might instruct that if the jury finds for the plaintiff, it is not to award nominal damages, but must award substantial damages. ${ }^{55}$ It might even be suggested

52 On the first appeal in the case, the court sustained a demurrer to a count by the plaintiff for a sharing of profits from defendant's book. The evidence of an invasion of privacy was flimsy, and recovery would have been more a windfall to the plaintiff than a protection of privacy. Perhaps the court desired to establish the action in that state. Compare Bunnell v. Keystone Varnish Co., r67 N.Y. Misc. 707, 4 N.Y.S. 2d. 60I (I938), aff'd 254 App. Div. 885, 5 N.Y.S. 2d 4 I5 (r938). Fear of strike suits is perhaps behind some of the skepticism as to sensibility.

53 See discussion in McCormick, Damages § 24 (1935).

54 Proof of pecuniary damages is not required. Munden v. Harris, I53 Mo. App. 652, 134 S.W. 1076 (rgrr). This position is now generally accepted.

55 There is no glory of vindication, as in a defamation action, in the recovery of a nominal judgment. If the jury asked for definitions of "nominal" and "substantial," the court could indicate that nominal damages are damages awarded in a trivial amount merely as a recognition of some breach of duty and not as a measure of recompense for loss or detriment sustained. Substantial damages are the result of an effort at measured compensation, and are to be contrasted with nominal damages, which are in no sense compensatory, but merely symbolic. McCormick, Damages § 20 (I935). 
that the court set a minimum figure for what constitutes a "substantial" sum, but this is open to query..$^{6}$

The difficulties found in common-law jurisdictions direct attention to the New York Civil Rights Law, ${ }^{57}$ the major legislation on privacy thus far enacted.

Development of the common law of New York prior to the decision in Roberson v. Rochester Folding Box Co. ${ }^{8}$ indicated that the right of privacy might have had an orderly growth in that state but for the refusal of the court in that case to recognize a common-law cause of action. ${ }^{59}$ The Civil Rights Law, passed in response to public demand, is now the exclusive measurement of any privacy action. Primarily concerned with remedying the type of situtation found in the Roberson case, where recovery for the unauthorized use of a picture on a commerical product was denied, "[t]he statute embodied a legal recognition ... of the right of a person to be let alone, a right directed 'against the commercial exploitation of one's personality." ",60

Recovery under the statute is limited by two important elements: I) the scope of the legislation, which is directed to commercial situations only, and 2) the application of policies protecting freedom of speech, and the tendency to a narrower construction where there is a penal provision.

The key phrases of the statute show clearly its commercial import. Publication must be of a "name, portrait or picture" of a living person for "advertising purposes" or "purposes of trade," made without written consent."

The word "picture" is comparatively unambiguous. "Portrait" and "name" have, however, caused some difficulty. A mannekin, if sufficient in likeness to the human model, is a portrait within the statute..$^{62}$ And in an early case the use

${ }^{56}$ There is a lack of precedent in setting a minimum figure. The usual difficulty is with excessive verdicts. Courts do not like to disturb jury findings and are reluctant to hold that there is a "right" to a substantial sum. There is a diffculty in setting a figure, which would depend on the locality and the times. Plaintiffs' lawyers might not feel the amount to be worthwhile if set too low and juries persisted in going no higher. Still, the minimum figure rule might avoid difficulties of inadequate verdicts and consequent retrials.

${ }_{57}$ "A person, frrm or corporation that uses for advertising purposes, or for the purpose of trade, the name, portrait or picture of any living person without having first obtained the written consent of such person, or if a minor of his or her parent or guardian, is guilty of a misdemeanor." N.Y. Civil Rights Law (McKinney, IgI6) c. 6, $\S 50$. "Any person whose name, portrait or picture is used within this state for advertising purposes or for the purposes of trade ... may maintain an equitable action ... to prevent and restrain the use thereof; and may sue and recover damages for any injuries sustained by reason of such use. . ." N.Y. Civil Rights Law (McKinney, I9I6), c. 6, §5 I.

${ }^{88} 17$ I N.Y. 538, 64 N.E. 442 (IgO2).

59 An exhaustive discussion of the cases is contained in Kacedan, The Right of Privacy, I2 B.U.L. Rev. 600, 6ro-34 (1932).

${ }^{60}$ Lahiri v. Daily Mirror, I62 N.Y. Misc. 776, 779, 295 N.Y. Supp. 382, 385 (1937), quoting Bohlen, Fifty Years of Torts, 5o Harv. L. Rev. 725, 73I (I937).

6x See note 57 supra.

62 Young v. Greneker Studios, x75 N.Y. Misc. I027, 26 N.Y.S. 2d 357 (194I); cf. Freed v. Loew's Inc., I 75 N.Y. Misc. 6I6, 24 N.Y.S. 2d 679 (1940). 
of the plaintiff's real name together with an impersonation of him in a moving picture was held to be a portrayal.$^{6_{3}}$ In Toscani $v$. Hersey, ${ }^{6}{ }_{4}$ however, an alleged impersonation without the use of the plaintiff's real name failed to bring the case within the precedent. The plaintiff alleged that his personality was characterized and that certain episodes from his life were used in the novel and stage play $A$ Bell for Adano.

Similarly, the statute has been held to apply only to legal names and not to those assumed coincidentally by both the plaintiff and defendant. ${ }^{65} \mathrm{~A}$ name assumed for business purposes only, and used exclusively by a corporation, is not protected.66

Other limitations are found in the phrases denoting the purpose of the publication. To come within "advertising purpose," the name, picture or portrait must appear in or be an actual part of an advertisement. ${ }^{67}$ And any use in a publication operated for profit where the use is to increase circulation does not automatically come within the meaning of "purposes of trade." Inclusion in either category may be prevented by the particular nature of the use. ${ }^{68}$

Granted that a publication has been fitted within the statutory phrases, the cause of action may nevertheless be lost because of strong policy notions of freedom of speech. ${ }^{69}$ If the item is one of public interest-which may include items of current news or of an educational and informative nature-the publication is privileged. ${ }^{70}$ In Koussevitzky v. Allen, Towne $\&$ Heath ${ }^{7 x}$ the plaintiff, an

${ }^{63}$ Binns v. Vitagraph Co. of America, 2I0 N.Y. 5I, 103 N.E. 1108 (1913).

${ }_{64} 27 \mathrm{I}$ App. Div. 445, 65 N.Y.S. 2d 8I4 (I946); cf. Levey v. Warner Bros. Pictures, 57 F. Supp. 40 (N.Y., 1944). Moving picture studios usually maintain legal research departments which check all material in a film in order that all possible similarities to real persons and places are obliterated. See N.Y. Times, p. $4 \S 2$, col. 3 (Nov. 30, r947). With the newer trend towards biographies of living or recently deceased persons, the studios first obtain legal clearance from the person or the estate before filming. See N.Y. Times, p. 24, $\$ 6$, col. 4 (Jan. 20, r946). Compare Kelley v. Loew's Inc., 76 F. Supp. 473 (Mass., I948) where plaintiff's signing of a release was held a waiver of a right of privacy action but not of libel.

65 Davis v. R.K.O. Radio Pictures, I6 F. Supp. I95 (N.Y., I936).

${ }^{66}$ Jaccard v. R. H. Macy \& Co., 176 N.Y. Misc. 88, 26 N.Y.S. 2d 829 (194r), aff'd 265 App. Div. 15,37 N.Y.S. 2d 570 (r 942$)$.

${ }^{6} 7$ Lahiri v. Daily Mirror, 162 N.Y. Misc. 776, 295 N.Y. Supp. 382 (I937); Jeffries v. New York Evening Journal Pub. Co., 67 N.Y. Misc. 570, 124 N.Y. Supp. 780 (1910).

${ }^{68}$ Martin v. New Metropolitan Fiction, Inc., 237 App. Div. 863, 260 N.Y. Supp. 972 (1932) (use of picture or name outside theatre as advertisement of picture within is not actionable).

69 "A free press is so intimately bound up with fundamental democratic institutions that, if the right of privacy is to be extended to cover news items and articles of general public interest, educational and informative in character, it should be the result of a clear expression of legislative policy." Sarat Lahiri v. Daily Mirror, r62 N.Y. Misc. 776, 782, 295 N.Y. Supp. 382, 388 (1937).

${ }^{70}$ Sweenek v. Pathé News, I6 F. Supp. 746 (N.Y., 1936) (newsreel of corpulent women at exercise constitutes public interest); cf. People v. Robert R. McBride \& Co., I59 N.Y. Misc. 5 , 288 N.Y. Supp. 50 I (1936). (I947).

${ }^{71}$ I88 N.Y. Misc. 479 , 68 N.Y.S. $2 d 779$ (1947), aff'd 272 App. Div. 759,69 N.Y.S. $2 d 432$ 
eminent conductor, failed to obtain relief for the unauthorized and possibly libelous publication of a biography. The court, following D'Altomonte v. New York Herald Co., ${ }^{72}$ held that biographies constituted a "legitimate dissemination of information on a subject of general interest." Nor did the advertisements and announcements of the forthcoming book constitute a violation of the statute. They were merely incidental to the biography.

The holdings in the biography cases are to be contrasted with the protection afforded against unauthorized portrayals in works of fiction. While not limited by the paramount considerations of freedom of press, recovery is not automatic. The plaintiff's name must have been used a sufficient number of times, ${ }^{73}$ and the inference must be sufficiently plain to the public that it is the plaintiff who is being portrayed. ${ }^{74}$ Comic books have been held to come within "purposes of trade," and are not privileged as educational. ${ }^{75}$

From this examination of the New York decisions it may be seen that many of the actions allowed in common-law jurisdictions would fail in that state. Relief would certainly be denied in all cases where the invasion was noncommercial. Actions for intrusions into private quarters, ${ }^{76}$ wire tapping and eavesdropping, ${ }^{77}$ public postings of a person's debts, ${ }^{78}$ unauthorized use of a person's name on a petition, ${ }^{79}$ and circulation of fingerprints and photographs among law-enforcing agencies ${ }^{80}$-all would fail if right of privacy were invoked.

Furthermore, the narrow construction given to the statute because of a policy of almost unrestricted freedom of the press would prohibit recovery in situations where even a tenuous assertion could be made that the informational value of a current news item outweighed distress to the subject of publication. ${ }^{8 x}$ The indirect commercial value in promotion of circulation as an argument for recovery would doubtless receive but nominal consideration. Even where both statutory (I9I3).

72 I54 App. Div. 453, I39 N.Y. Supp. 200 (I9I3), modified by 208 N.Y. 596, I02 N.E. Iror

${ }_{73}$ Damron v. Doubleday, Doran \& Co., I33 N.Y. Misc. 302, 23I N.Y. Supp. 444 (I928), aff'd 226 App. Div. 796, 234 N.Y. Supp. 773 (x928) (single appearance of the plaintiff's name is insufficient); Krieger v. Popular Publications, Inc., I67 N.Y. Misc. 5, 3 N.Y.S. 2d 480 ( 1938 ) (use of the plaintiff's name about one hundred times is actionable).

${ }^{74}$ Nebb v. Bell Syndicate, 4 I F. Supp. 929 (N.Y., I94I); Swacker v. Wright, I54 N.Y. Misc. 822, 277 N.Y. Supp. 296 (r935).

75 Molony v. Boy Comics Publishers, Inc., I88 N.X. Misc. 450, 65 N.Y.S. 2d 173 (r946).

${ }^{76}$ Byfield v. Candler, 33 Ga. App. 275, I25 S.E. 905 (x924); cf. DeMay v. Roberts, 46 Mich. r60, 9. N.W. $x_{46} 6$ (r88 $\mathrm{x}$ ).

77 McDaniel v. Atlanta Coca-Cola Bottling Co., 60 App. 92, 2 S.E. 2d 8ro (r939); Rhodes v. Graham, 238 Ky. 225, 37 S.W. $2 d{ }_{4} 6$ (r93r).

${ }^{78}$ Trammell v. Citizens News Co., 285 Ky. 529, I48 S.W. $2 \mathrm{~d} 708$ (I94I); Brents v. Morgan, $221 \mathrm{Ky} .765,299$ S.W. 967 (1927).

79 Hinish v. Meier \& Frank Co., I66 Ore. 482, II3 P. 2d 438 (I94r).

${ }^{80}$ See note 7 supra.

${ }^{8 x}$ See text at note 27 supra. 
and common-law invasions are pleaded in alternative causes of action as in the Sidi $^{82}$ case, the same statutory policy seems to determine the result.

It seems inescapable that the New York statute and decisions do not offer a clear-cut rationale for protection of privacy. Comprehensive protection against commercial use of some aspect of the personality has not been afforded. Relief is given for the use of a famous name in an unauthorized endorsement but the same name may be used with impunity in a biography, though not in a comic book. The difficulties of interpretation and the limits of protection suggest that common-law flexibility is better suited for the necessarily widely varied fact situations found in privacy actions.

\section{COMMON-LAW CRIMINAL CONSPIRACY AS A WEAPON AGAINST CORRUPT POLITICAL ORGANIZATIONS}

Machine control over patronage has been the greatest barrier to the unseating of the self-perpetuating big-city political machine by the conventional election process. As a result, various oblique methods have been used in order to restore popular, democratic control. An example of one such method was the indictment for criminal conspiracy of Mayor McFeely of Hoboken, New Jersey. It is proposed first to examine in what ways the members of this political machine overreached themselves and how this was turned into a weapon which helped drive the machine from power, and then to consider the desirability of using this weapon against other entrenched political machines.

Mayor McFeely was an extreme example of the political boss. Although he never received a salary of over $\$ 5,000$ a year as Mayor, he amassed a fortune estimated at $\$ 3,000,000$." "Tall, bald, and sour-faced, he did not even afford his subjects the dubious pleasure of watching him make public appearances. $\mathrm{He}$ made almost no speeches (his grammar was too bad), took no interest in parades, and rode around in a bullet-proof Cadillac. . . . Under his rule Hoboken taxes went sky-high, building almost ceased." 3 The McFeely family had been in power so long that "the roster of the police department read like the fly-leaf of the family Bible." 4

After twenty-two years of McFeely's rule, public frustration finally found expression in an indictment for common-law criminal conspiracy. 5 This indictment named the Mayor, the Director and Deputy Director of Public Safety, the Chief and Deputy Chief of Police, and other superior officers of the De-

${ }^{82}$ See text following note 29 supra; see also note 35 supra.

I State v. McFeely, 52 A. 2d 823 (Ct. Quart. Sess. N.J., r947).

222 Life, No. 2x, at 4I (May 26, I947).

${ }^{3} 49$ Time, No. 2r, at 28 (May 26, I947).

429 Newsweek, No. 21, at 23 (May 26, I947).

s State v. McFeely, 52 A. 2d 823 (Ct. Quart. Sess. N.J., I947) 